\title{
Correction to: An analytical pipeline for identifying and mapping the integration sites of HIV and other retroviruses
}

Daria W. Wells ${ }^{1}$, Shuang Guo ${ }^{1}$, Wei Shao², Michael J. Bale 3 , John M. Coffin ${ }^{4}$, Stephen H. Hughes ${ }^{3}$ and Xiaolin Wu*

\section{Correction to: BMC Genomics 21, 216 (2020) \\ https://doi.org/10.1186/s12864-020-6647-4}

Following publication of the original article [1], it was reported that Additional file 1 was missing the supplemental figures (Figs. S1-S6) referenced in the file. The complete Additional file including the missing figures is provided in this Correction.

\section{Supplementary information}

Supplementary information accompanies this paper at https://doi.org/10. 1186/s12864-020-06924-0.

Additional file 1:.

\begin{abstract}
Author details
${ }^{1}$ Cancer Research Technology Program, Leidos Biomedical Research, Inc., Frederick National Laboratory for Cancer Research, PO Box B, Frederick, MD 21702, USA. ${ }^{2}$ Advanced Biomedical Computational Science, Leidos Biomedical Research, Inc., Frederick National Laboratory for Cancer Research, Frederick, MD, USA. ${ }^{3}$ HIV Dynamics and Replication Program, National Cancer Institute Frederick, National Institutes of Health, Frederick, MD, USA.

${ }^{4}$ Department of Molecular Biology and Microbiology, Tufts University, Boston, MA, USA.
\end{abstract}

Published online: 29 July 2020

\section{Reference}

1. Wells DW, Guo S, Shao W, et al. An analytical pipeline for identifying and mapping the integration sites of HIV and other retroviruses. BMC Genomics. 2020;21:216. https://doi.org/10.1186/s12864-020-6647-4.

\footnotetext{
The original article can be found online at https://doi.org/10.1186/s12864020-6647-4.

* Correspondence: forestwu@mail.nih.gov

'Cancer Research Technology Program, Leidos Biomedical Research, Inc., Frederick National Laboratory for Cancer Research, PO Box B, Frederick, MD 21702, USA

Full list of author information is available at the end of the article
}

(c) The Author(s). 2020 Open Access This article is licensed under a Creative Commons Attribution 4.0 International License, which permits use, sharing, adaptation, distribution and reproduction in any medium or format, as long as you give appropriate credit to the original author(s) and the source, provide a link to the Creative Commons licence, and indicate if changes were made. The images or other third party material in this article are included in the article's Creative Commons. licence, unless indicated otherwise in a credit line to the material. If material is not included in the article's Creative Commons licence and your intended use is not permitted by statutory regulation or exceeds the permitted use, you will need to obtain permission directly from the copyright holder. To view a copy of this licence, visit http://creativecommons.org/licenses/by/4.0/ The Creative Commons Public Domain Dedication waiver (http://creativecommons.org/publicdomain/zero/1.0/) applies to the data made available in this article, unless otherwise stated in a credit line to the data. 